\title{
PENINGKATAN AKTIVITAS DAN PRESTASI BELAJAR SISWA KELAS I SD N II SOKOMOYO KAB. KULON PROGO YOGYAKARTA \\ (Penelitian Tindakan Kelas Menggunakan Alat Peraga Pada Mata Pelajaran Agama Buddha Kelas I Materi Lambang-Lambang Buddhis)
}

\author{
Sudarto ${ }^{1}$ \\ Mujiyanto, S.Ag., M.Pd. ${ }^{2}$ \\ Situ Asih, S.Pd.B., M.Ikom ${ }^{3}$
}

\begin{abstract}
Abstrak
Tujuan dalam penelitian ini adalah untuk mengetahui peningkatan aktivitas siswa dan prestasi belajar dengan menggunakan media alat peraga pada mata pelajaran lambang-lambnag Buddhis. Penelitian ini menggunakan penelitian tindakan kelas (PTK) yang dilakukan si SD N II Sokomoyo pada bulan April-Juni 2015. Kelas penelitian yang digunakan kelas I. Penelitian ini terdiri dari tiga siklus. Hasil penelitian menunjukan bahwa keaktivan siswa dan prestasi belajar siswa kelas I Sekolah Dasar Negeri II Sokomoyo sudah mengalami peningkatan dengan menggunakan media alat peraga. Peningkatan prestasi belajar dari siklus I sebesar 20\% selanjutnya siklus III menjadi $60 \%$ dengan menunjukan peningkatan dari siklus I ke siklus II yaitu $40 \%$ dan siklus III meningkat menjadi $100 \%$ hal ini menujukan peningkatan $60 \%$ dengan seluruh siswa tuntas dan memperoleh nilai diatas Kriteria Ketuntasan Minimal.
\end{abstract}

Kata Kunci: Aktivitas Belajar Siswa, Prestasi Belajar Siswa, Media Alat Peraga

\section{Abstract}

The purpose of this study was to determine the increase in student activity and learning achievement by using teaching aids on subjects of Buddhist symbols. This study uses a classroom action research (CAR) conducted by SD N II Sokomoyo in April-June 2015. The research class used was class I. This study consisted of three cycles. The results showed that student activity and student achievement in class I of the Sokomoyo State Elementary School II had increased by using teaching aids. Improved learning achievement from cycle I by $20 \%$ then cycle III to $60 \%$ by showing an increase from cycle I to cycle II that is $40 \%$ and cycle III increased to $100 \%$ this is aimed at an increase of $60 \%$ with all students completing and getting grades above the Completion Criteria At a minimum.

Keywords: Student Learning Activities, Student Learning Achievements, Media Props

\footnotetext{
${ }^{1}$ Prodi Dharmacarya Email: dartosudarto13@gmail.com

${ }^{2}$ Dosen STABN Raden Wijaya Email: mujiyanto009@ gmail.com

${ }^{3}$ Dosen STABN Raden Wijaya Email: situasih@yahoo.co.id
} 


\section{PENDAHULUAN}

Sekolah menjadi salah satu tempat berlangsungnya kegiatan belajar mengajar yang secara umum menjadi tanggung jawab Pemerintah. Peranan Pemerintah dalam menyelenggarakan sekolah berbentuk keterlibatan penentuan sistem dan isi pendidikan. Mengenai sistem pendidikan di dasarkan pada lamanya jangka waktu seseorang mencapai kedewasaannya, hal ini nampak jelas dengan penyelenggaraan sekolah secara bertingkat dan proses belajar mengajarnya dalam bentuk klasikal. Sedangkan isi pendidikan ini dituangkan dalam bentuk kurikulum. Kurikulum yang tersusun akan diaplikasikan di sekolah yaitu pada proses pendidikan atau pembelajaran yang dilakukan oleh guru di sekolah.

Wina Sanjaya (2006:

mengemukakan bahwa kegiatan pembelajaran merupakan kegiatan yang melibatkan beberapa komponen: (1) Siswa : Seorang yang bertindak sebagai pencari, penerima, dan penyimpan isi pelajaran yang dibutuhkan untuk mencapai tujuan. (2).Guru: Seseorang yang bertindak sebagai pengelola, katalisator, dan peran lainnya yang memungkinkan berlangsungnya kegiatan belajar mengajar yang efektif. (3). Tujuan: Pernyataan tentang perubahan perilaku (kognitif, psikomotorik, afektif) yang diinginkan terjadi pada siswa setelah mengikuti kegiatan pembelajaran.(4). Isi Pelajaran: Segala informasi berupa fakta, prinsip, dan konsep yang diperlukan untuk mencapai tujuan.(5). Metode: Cara yang teratur untuk memberikan kesempatan kepada siswa untuk mendapat informasi yang dibutuhkan mereka untuk mencapai tujuan. (6). Media: Bahan pengajaran dengan atau tanpa peralatan yang digunakanuntuk menyajikan informasi kepada siswa. (7). Evaluasi: Cara tertentu yang digunakan untuk menilai suatu proses dan hasilnya.

Proses Belajar Mengajar (PBM) sangat memerlukan peran aktif guru dalam memberikan pengetahuan untuk menghasilkan siswa yang berkualitas serta siap untuk melanjutkan jenjang pendidikan yang lebih tinggi. Proses Belajar Mengajar perlu ditata secara terkoordinasi, terpadu, efektif dan efisien. Indonesia merupakan salah satu bangsa yang berkembang, sehingga harus menempatkan aspek pendidikan pada posisi yang sangat penting, karena pembangunan hanya dapat dicapai dengan cara memperluas dan mengembangkan proses belajar mengajar dalam lingkungan pendidikan baik secara formal maupun non formal. Tercapainya proses belajar mengajar tidak bisa terlepas dari kemampuan seorang guru dalam memberikan pelajaran di kelas. Hal tersebut dikarenakan kemampuan guru menjadi ujung tombak tercapainya pembelajaran.

Sesuai dengan eksistensinya di sekolah, tugas utama seorang guru adalah mengajar sehingga setiap mengajar seseorang guru harus mempersiapkan suatu cara bagaimana agar yang diajarkan kepada siswa itu dapat diterima serta dapat dipahami dengan mudah salah satu kemampuan yang harus diterapkan oleh seorang guru adalah mampu menggunakan berbagai macam media untuk membantu proses belajar mengajar hal tersebut dikarenakan proses belajar mengajar 
merupakan kegiatan guru di sekolah sebab kemampuan siswa dalam menerima pelajaran didukung oleh berbagai faktor yang mempengaruhinya, salah satu faktor tersebut adalah media yang digunakan dalam pembelajaran dikarenakan media pendidikan sebagai salah satu sarana meningkatkan mutu pendidikan sangat penting dalam proses belajar mengajar.

Media pembelajaran mempunyai peran sangat penting untuk mengantar siswa mencapai pada tujuan pembelajaran dengan lebih jelas. Salah satu contoh yang dapat diambil adalah siswa tidak akan memahami bahwa bumi itu bulat tanpa ada media peraga Globe dan Atlas. Seperti halnya pembelajaran Pendidikan agama Buddha pada materi lambang-lambang Buddhis yang sulit untuk dipahami dikarenakan siswa belum mampu memahami secara konkrit mengenai lambanglambang Buddhis, sebab usia siswa yang duduk di bangku kelas I sekolah dasar berkisar berumur 7 tahun dengan hal ini siswa belum mampu berfikir abstrak, maka dengan menggunakan media alat peraga seperti miniatur Stupa, Swastika, Roda Dhamma dan lain sebagainya dalam pembelajaran pendidikan agama Buddha siswa mampu memahami materi secara mendalam.

Pada jaman Sang Buddha, Sang Buddha bersabda yang tercantum di dalam Sutta Samyutta Nikaya IV ,15 :

" pengetahuan manusia adalah segala sesuatu yang dijangkau oleh mata dan bentuk materi, telinga dan bunyi, hidung dan bau, lidah dan rasa, badan dan objek-objek sentuhan, pikiran dan objek mental" dalam Krisnanda (2003: 320).

Berdasar pendapat di atas dapat di garis bawahi bahwa untuk mendapatkan persepsi lewat indera diperlukan adanya media untuk mempermudah pemahaman karena penggunaan media pembelajaran dalam proses pendidikan dapat membantu proses belajar siswa dalam poses belajar mengajar yang pada gilirannya dapat mempertinggi hasil belajar yang dicapainya. Manfaat media pembelajaran dengan menggunakan alat peraga pada materi lambang-lambang Buddhis diharapkan akan memotivasi siswa untuk belajar mandiri, kreatif, efektif, efisien, meningkatkan aktifitas belajar siswa dan prestasi belajar.

Beberapa upaya telah dilakukan untuk mengatasi masalah di atas, salah satunya adalah menggunakan alat peraga, menurut Piaget (dalam Wuryani, 2006: 73) mengungkapkan bahwa, tahapan-tahapan perkembangan kognitif pada anak di usia 2-7 tahun atau yang disebut dengan tahapan praoperasional anak memasuki tahapan perkembangan yang menggunakan simbolsimbol yang menggunakan gambaran objek yang ada disekitarnya, berpikirnya masih egosentris dan berpusat.

Berdasarkan dari pendapat Piaget di atas dapat ditarik kesimpulan bahwa usia anak memasuki 2-7 tahun dalam penerimaan pembelajaran yang diberikan membutuhkan benda konkrit yaitu gambar-gambar dan simbol-simbol untuk memudahkan pemahaman siswa, karena pada usia 2-7 tahun siswa memasuki tahapan perkembangan 
kognitif pada praoperasional atau belum bisa berfikir abstrak.

Melihat pentingnya media tersebut maka, perlu diterapkan dalam proses belajar mengajar di sekolah. Salah satunya dengan menggunakan media alat peraga. Media mempunyai fungsi yang sangat baik untuk meningkatkan prestasi belajar yang maksimal (Daryanto,2010: 3). Dengan demikian siswa lebih mudah dalam pemahaman materi pembelajaran dengan metode ini bertujuan untuk meningkatkan minat siswa, aktifitas siswa dan prestasi belajar siswa supaya dalam proses belajar mengajar tercipta suasana yang kondusif. Apabila suasana yang kondusif telah tercapai maka aktifitas dan prestasi belajar siswa akan meningkat. Tidak hanya aktifitas dan prestasi belajar siswanya saja yang meningkat tetapi juga kemampuan siswa dalam menguasai materi akan meningkat. Melihat keadaan tersebut mendorong peneliti untuk melakukan penelitian dengan harapan melalui penerapan penggunakan alat peraga lambang-lambang Buddhis dalam mata pelajaran Pendidikan Agama Buddha di Kelas I SD N II Sokomoyo mampu meningkatkan aktivitas belajar siswa dan prestasi belajar siswa. Sehingga diperoleh hasil yang maksimal.

\section{Aktifitas Belajar}

Menurut Kamus Besar Bahasa Indonesia disebutkan aktivitas berasal dari kata kerja akademik aktif yang berarti giat, rajin, selalu berusaha bekerja atau belajar dengan sungguh-sungguh supaya mendapat prestasi yang gemilang (Kamus Besar Bahasa
Indonesia, 2007: 12). Pengertian lain dikemukakan oleh Wijaya yaitu:

"Keterlibatan intelektual dan emosional siswa dalam kegiatan belajar mengajar, asimilasi (menyerap) dan akomodasi (menyesuaikan) kognitif dalam pencapaian pengetahuan, perbuatan, serta pengalaman langsung dalam pembentukan sikap dan nilai" (Wijaya, 2007: 12).

Selanjutnya Rosseau (dalam Sardiman, 2000: 96) menyatakan bahwa dalam belajar segala pengetahuan harus diperoleh dengan pengamatan sendiri, pengalaman sendiri, dengan bekerja sendiri, dengan fasilitas yang diciptakan sendiri, baik secara rohani maupun teknis. Hal ini menunjukkan bahwa setiap siswa harus aktif, tanpa adanya aktivitas maka proses belajar tidak mungkin terjadi. Lebih lanjut Montessori menegaskan bahwa anakanak itu memiliki tenaga-tenaga untuk berkembang sendiri, membentuk sendiri, dan pendidik akan berperan sebagai pembimbing dan mengamati bagaimana perkembangan anak didiknya (Montessory dalam Sardiman, 2000: 96).

Berdasarkan beberapa pendapat di atas dapat dijelaskan bahwa siswa belajar dengan sendirinya melalui pengamatan sendiri, pengalaman sendiri dan bekerja sendiri dengan demikian siswa harus aktif dalam mengikuti pembelajaran guna mendukung tercapainya proses belajar mengajar yang optimal dan memperoleh nilai yang maksimal.

\section{Prestasi Belajar}

Menurut Pius A. Partanto \& M. Dahlan Al Barry (1994: 623) prestasi belajar dapat diartikan sebagai hasil yang telah diperoleh karena adanya aktivitas belajar yang telah 
dilakukan. Menurut Mulyono Abdurrahman (1999: 39) mengungkapkan bahwa hasil belajar atau prestasi belajar merupakan keluaran (output) dari suatu system pemrosesan masukan (input), masukan dari sistim tersebut berupa macam-macam informasi sedangkan keluaranya adalah perbuatan atau kinerja (performance). Prestasi belajar adalah hasil yang diperoleh berupa kesan-kesan yang mengakibatkan perubahan dari individu sebagai hasil dari aktivitas dalam belajar (Djamarah, 1994: 23). Slameto (2003 : 10) menyatakan bahwa prestasi belajar merupakan suatu perubahan yang dicapai seseorang setelah mengikuti proses belajar.

Prestasi belajar sangat erat hubunganya dengan kecerdasan intelektual tetapi dengan demikian tidak semata-mata hanya itu saja melainkan prestasi belajar juga dapat dilihat dari segi agama yang dapat dilihat dari segi kecerdasan spiritualnya, untuk itu pendidikan agama Buddha perlu untuk diberikan pada setiap jenjang pendidikan. Pentingnya pendidikan agama Buddha bagi siswa beragama Buddha, sesuai dengan CakkavatiSihananda Sutta dalam buku Panduan Tipitaka Kitab Suci Agama Buddha yang berbunyi:

"Para Bhikkhu, jadilah pulau bagi diri kalian, jadilah pelindung bagi dirimu sendiri, jangan ada perlindungan lainya, Jadikan Dhamma sebagai pulau bagi dirimu, jadikan Dhamma sebagai pelindungmu, jangan ada perlindungan lain" (Lanny Anggawati dan Wena Cintiawati, 2000: 63).

Syair di atas mempunyai makna, yaitu dengan memperoleh sendiri mempelajari Dhamma, maka seseorang akan memiliki pengetahuan yang dapat menjadi pelindung bagi dirinya sendiri. Dhamma dalam dunia pendidikan dapat diibaratkan ilmu pengetahuan, sehingga dengan memperoleh ilmu pengetahuan siswa akan dapat mengembangkan dirinya menjadi lebih baik dan terhindar dari kebodohan.

\section{Pengertian Media}

Menurut Kamus Besar Bahasa Indonesi kata media berarti perantara: penghubung; yang terletak di antara dua pihak (orang, golongan, dsb). Kata "media" berasal dari bahasa latin dan merupakan bentuk jamak dari kata medium yang berarti perantara atau pengantar. Menurut Sadiman (2005:6), media adalah perantara atau pengantar pesan dari pengirim ke penerima. Sedangkan Hamzah B dan Nina (2011:122) media adalah segala bentuk alat komunikasi yang dapat digunakan untuk menyampaikan informasi dari sumber ke siswa.

$$
\text { Gerlach \& Ely (1971: 03) }
$$
mengungkapkan bahwa media apabila dipahami secara garis besar adalah manusia, materi, atau kejadian yang membangun kondisi yang membuat siswa mampu memperoleh pengetahuan, keterampilan, atau sikap. Secara lebih khusus, pengertian media dalam proses belajar mengajar cenderung diartikan alat-alat grafis, fotografis, atau elektronis untuk menangkap, memproses, dan menyusun kembali informasi visual dan verbal. Berdasarkan uraian di atas disimpulkan bahwa media adalah alat bantu apa saja yang dapat dijadikan sebagai penyalur pesan guna mencapai tujuan pengajaran.

\section{Pengertian Media Alat Peraga}


Menurut Sujana dan Ahmad Rivai (1990: 128) Alat peraga adalah alat yang dipergunakan guru untuk membantu memperjelas materi pelajaran yang disampaikan kepada siswa dan mencegah terjadinya verbalisme pada diri siswa selanjutnya ditegaskan oleh Hamalik (1994: 213) alat bantu belajar adalah semua alat yang dapat digunakan untuk membantu siswa melakukan perbuatan belajar, sehingga kegiatan belajar menjadi lebih efesien dan efektif.

Pada zaman Sang Buddha penggunaan media pengajaran dengan menggunakan alat peraga juga digunakan dalam membantu Bhikkhu Cula Panthaka untuk membersihkan kekotoran-kekotoran batin sehingga Bhikkhu Cula Panthaka mencapai tingkat kearahatan dan memiliki Patisambhidhi yang terdapat di Dhammapada Atthakhatha (dalam Bhikkhu Buddhaghosa 2007: 364). Sang Buddha bersabda:

"Cula Panthaka tetaplah berada disini, menghadaplah Timur, gosoklah kain ini, sementara kau lakukanya dengan mengucapkan kata: "Rajo Haranam" (Bersih dari kekotoran) berulang-ulang”.

Bedasarkan kalimat di atas dapat disimpulkan bahwa seorang Guru mampu memilih media yang digunakan dalam pengajaran sehingga siswa mampu menerima dan memahami mengenai materi yang disampaikan hingga siswa memperoleh hasil yang maksimal, seperti halnya dari cerita Bhikku Cula Panthaka yang sangat lemah dalam pemahan menghafal setiap syair-syair dari ajaran Dhamma Sang Buddha sehingga Sang Memilih media dengan menyuruh
Bhikkhu Cula Panthaka untuk menggosokgosokan kain dengan mengucap "Rajo Haranam" secara berulang-ulang, inilah penggunaan media yang digunakan pada zaman sang Buddha sehingga Bhikku Cula Panthaka mencapai tingkat kearahatan dan memiliki Patisambhidi atau kesanggupan untuk mengerti dan mengetahui Dhamma serta mengajarkanya, bila dikaitkan dengan proses belajar mengajar saat ini pencapaian kearahatan dan Patisambhidi ini adalah siswa yang mampu memahami materi dengan jelas sehingga mendapatkan nilai yang maksimal.

\section{Fungsi Media Pembelajaran Dengan Alat}

Peraga

Menurut Azhar Arsyad ( 2011: 101) ada enam fungsi pokok dari alat peraga dalam proses belajar. Keenam fungsi tersebut yaitu:

a. Penggunaan alat peraga dalam proses belajar mengajar bukan merupakan fungsi tambahan tetapi mempunyai fungsi tersendiri sebagai alat bantu untuk mewujudkan situasi belajar mengajar yang efektif.

b. Penggunaan alat peraga merupakan bagian yang integral dari keseluruhan situasi mengajar. Ini berarti bahwa alat peraga merupakan salah satu unsur yang harus dikembangkan oleh guru.

c. Alat peraga dalam pengajaran penggunaanya integral dengan tujuan dan isi pelajaran.

d. Penggunaan alat peraga dalam pengajaran bukan semata-mata alat hiburan, dalam digunakan hanya sekedar melengkapi proses belajar supaya lebih menarik perhatian siswa.

e. Penggunaan alat peraga dalam pengajaran lebih diutamakan untuk mempercepat proses belajar mengajar dan membantu siswa dalam menangkap pengertian yang diberikan guru.

f. Penggunaan alat peraga dalam pengajaran diutamakan untuk mempertinggi mutu belajar mengajar. Dengan perkataan lain bahwa penggunaan alat peraga dalam 
proses belajar mengajar hasil belajar yang dicapai akan tahan lama diingat oleh siswa, sehingga pelajaran mempunyai nilai yang tinggi.

Arsyad (2011: 15) menuturkan fungsi media pembelajaran dalam proses belajar mengajar yaitu “... sebagai alat bantu mengajar yang turut mempengaruhi iklim, kondisi, dan lingkungan belajar yang ditata dan diciptakan oleh guru". Selanjutnya menurut Sanaky (2009: 15), media pengajaran berfungsi untuk merangsang pembelajaran dengan: (1) membuat duplikasi dari objek yang sebenarnya; (2) membuat konsep abstrak ke konsep konkret; (3) memberi kesamaan persepsi; (4) mengatasi hambatan waktu, tempat, jumlah, dan jarak; (5) menyajikan ulang informasi secara konsisten; (6) memberi suasana belajar yag tidak tertekan, santai, dan menarik sehingga tujuan penbelajaran tercapai.

Sadiman dkk (2009: 17) menjabarkan kegunaan-kegunaan media sebagai berikut: (1) memperjelas penyajian pesan agar tidak hanya berupa kata-kata tertulis atau lisan saja; (2) mengatasi keterbatasan ruang, waktu, dan daya indera; (3) penggunaan media yang bervariasi dapat mengatasi kepasifan siswa karena media berfungsi untuk menimbulkan kegairahan belajar dan memungkinkan interaksi yang lebih langsung antara siswa dengan lingkungan dan kenyataan; (4) media pendidikan secara tidak langsung dapat mengatasi permasalahan-permasalahan yang bersifat internal maupun eksternal seperti karakteristik siswa dan lingkungan yang berbeda-beda sedangkan penyajian kurikulum disamaratakan untuk semua siswa. Media akan membantu kerja guru dalam rangka menyamakan persepsi sehingga kegiatan belajar mengajar berlangsung dengan baik dalam keragaman siswa.

Beberapa penjelasan mengenai fungsi media pengajaran di atas jelas bahwa dengan dengan media guru mampu menjembatani kesulitan siswa dalam belajar sekaligus menjadi alat bantu yang sangat efektif bagi guru serta media memberikan variasi dalam proses belajar mengajar sehingga perhatian siswa pada pelajaran lebih besar dan pelajaran yang diberikan mudah diingat dan dipahami.

\section{METODE PENELITIAN}

Penelitian ini merupakan Classroom Action Research (CAR) atau Penelitian Tindakan Kelas (PTK), yaitu penelitian tindakan yang dilaksanakan sebagai strategi pemecahan masalah dengan memanfaatkan tindakan nyata kemudian melakukan refleksi terhadap hasil tindakan. Hasil tindakan dan refleksi tersebut dijadikan sebagai langkah pemilihan tindakan berikutnya sesuai dengan permasalahan yang dihadapi.

Menurut Suharsimi (2002: 6) menggabungkan tiga kata istilah, yaitu penelitian, tindakan, dan kelas, yang menunjukkan bahwa penelitian tindakan kelas merupakan suatu pencermatan terhadap kegiatan belajar berupa sebuah tindakan yang sengaja dimunculkan dan terjadi dalam sebuah kelas secara bersama. Sedangkan menurut Rupoport (Rochiati, 2008:11) mengartikan penelitian tindakan kelas yaitu untuk membantu mengatasi permasalahan praktis yang dihadapi dalam situasi darurat dan membantu pencapaian tujuan ilmu sosial 
dengan kerja sama dalam etika yang disepakati bersama.

Penelitian ini dilakukan dengan melalui beberapa siklus untuk memperoleh penoingkatan aktivitas siswa dan prestasi belajar siswa dalam proses pembelajaran. Kegiatan refleksi, observasi dilakukan oleh peneliti untuk melakukan evaluasi-evaluasi pada siklus pertama hingga siklus terakhir. Dengan demikian penggunaan metode Penelitian Tindakan Kelas ini menjadi lebih efektif.

\section{HASIL DAN PE,MBAHASAN}

\section{A. Deskripsi Kondisi Awal}

Penelitian tindakan kelas dilakukan di SD N II Sokomoyo kelas I dengan jumlah siswa 5 siswa yang terdiri 3 siswa laki-laki dan 2 siswa perempuan dengan rata-rata umur 7 tahun. Proses belajar mengajar pendidikan agama Buddha pada materi lambang-lambang Buddhis dilakukan dengan metode ceramah dan keaktivan pada proses belajar mengajar hanya pada Guru dan siswa belum aktif. Kurangnya inovasi dalam pembelajaran siswa kurang semangat dalam mengikuti pembelajaran dan siswa jenuh sehingga prestasi belajar siswa dan keaktivan siswa menjadi rendah.

Data dari kondisi awal yang diperoleh peneliti adalah prestasi belajar siswa dengan melakukan pre test. Hasil pre test sebelum diadakan tindakan menggunakan media alat peraga peneliti. Kompetensi Kelulusan Minimum KKM) pada pendidikan agama Buddha di SD N II Sokomoyo adalah 75 . berdasarkan hasil pre test yang diperoleh peneliti dari 5 siswa masih ada yang belum tuntas dengan nilai di atas KKM. Berikut data hasil pre test yang diperoleh oleh peneliti:

Tabel:1

Kondisi Awal Ketuntasan Belajar Siswa Kelas I

\begin{tabular}{|l|c|c|c|}
\hline No & Kriteria & $\begin{array}{c}\text { Frekuen } \\
\text { si }\end{array}$ & Presentase \\
\hline 1 & Tuntas & 1 & $20 \%$ \\
\hline 2 & Tidak & 4 & $80 \%$ \\
& Tuntas & & \\
\hline
\end{tabular}

Sumber: Diolah oleh peneliti

\section{B. Siklus I}

\section{Perencanaan Siklus I}

Kegiatan awal peneliti sebelum berada di kelas untuk melakukan tindakan penelitian yaitu mempersiapkan segala sesuatu yang menunjang pada proses belajar mengajar yang sesuai pada materi pembelajaran pada lambang-lambang Buddhis dengan menggunakan alat peraga guna mengatasi masalah pada proses belajar mengajar yang sudah diketahui tentang kondisi awal pada keaktifan siswa dan hasil belajar siswa pada mata pelajaran agama Buddha.

Hal yang diperlukan tersebut diantaranya Rencana Pelaksanaan Pembelajaran (RPP) dengan menggunakan alat bantu media alat peraga, menyusun pre test dan post test, lembar observasi pembelajaran, lembar observasi pada siswa, lembar angket penilaian aktivitas siswa, lembar observasi pada guru serta lembar wawancara pada guru dan siswa, hal-hal inilah yang terpenting untuk dipersiapkan sebelum 
melakukan tindakan penelitian di dalam kelas.

\section{Pelaksanaan Siklus I}

a) Siklus I Pertemuan 1

Pada pertemuan tindakan pertama membaca doa Namakarapatha yang dipimpin oleh salah satu siswa, dilanjutkan dengan mengabsensi kehadiran siswa serta memberikan motivasi kepada siswa selanjutnya pemberian soal pre test dan angket keaktifan pada siswa yang berkaitan dengan materi lambanglambang Buddhis.

Guru bersama peneliti membagikan soal pre test dan angket keaktifan kepada siswa untuk mengetahui kemampuan siswa tentang materi lambanglambang Buddhis serta mengetahui keaktifan siswa . setelah soal pre test dan angket keaktifan dibagikan peneliti memberikan peetunjuk pengisiannya, kemudian guru dan peneliti bersama-sama mengawasi dan memperhatikan siswa yang mengerjakan soal maupun angket. Soal-soal pre test dan angketselesai dikerjakan oleh siswa selama kurang lebih 15 menit. Guru meneliti jawaban soal yang telah terkumpul dan memastikan soal dijawab semua.

Setelah mengerjakan soal guru melanjutkan dengan penyampaian materi yang terkait dengan materi lambang-lambang Buddhis serta memberikan gambaran-gambaran umum mengenai lambang-lambang Buddhis namun pada pertemuan ini setelah guru menjelaskan materi siswa belum begitu paham dengan materi yang disampaikan siswa pun masih diam dan malu untuk bertanya kepada guru sehingga belum aktif dalam mengikuti pembelajaran. Pada akhir pembelajaran ditutup dengan pembacaan doa Namakarapatha dan guru memberikan salam Buddhis.

\section{b) Siklus I Pertemuan 2}

$$
\text { Pada pertemuan yang }
$$

kedua ini guru dan peneliti berkolaborasi melaksanakan proses belajar mengajar pendidikan agama Buddha pada materi lambang-lambang Buddhis dengan menggunakan media alat peraga, proses ini adalah lanjutan dari pertemuan yang pertama. Pada pertemuan pertama melakukan pre test dan kemudian dilanjutkan dengan pemaparan materi secara singkat, namun pada pertemuan kedua ini, guru menggunakan media alat peraga guna membantu menyampaikan materi yang terkait.

Kegiatan selanjutnya pada pertemuan kedua ini sama dengan 
proses belajar mengajar pada pertemuan yang pertama, namun pada pertemuan yang kedua ini pada kegiatan proses belajar mengajar dilaksanakan dengan mengacu pada RPP yang telah dipersiapkan oleh peneliti sebelumya. Kegiatan pembelajaran pada pertemuan yang kedua ini diawali dengan membacakan doa Namakarapatha yang dipimpin oleh salah satu siswa dan kemudian dilanjutkan dengan salam Buddhis. Setelah itu guru mengabsensi Siswa, serta menyampaikan tujuan pemebelajaran yang akan dicapai dalam proses belajar mengajar dan tidak lupa guru menyampaikan motivasi-motivasi kepada Siswa.

Pada inti proses belajar mengajar guru menjelaskan materi yang berkaitan dengan lambang-lambang Buddhis dengan menyebutkan satu persatu dari berbagai macam lambang Buddhis serta memberikan penjelasan mengenai makna dari masing-masing LambangLambang Buddhis dengan menggunakan media alat peraga, guru memberikan kesempatan seluas-luasya kepada siswa untuk bertanya mengenai materi yang belum paham. Siswa terlihat sangat antusias memperhatikan penjelasan guru karena guru menjelaskan materi dengan menggunakan alat bantu sehingga siswa lebih paham mengenai berbagai macam lambanglambang buddhis serta makna satu persatu dari masing-masing lambang-lambang Buddhis dan siswa sangat aktif dalam menjawab pertanyaan yang diberikan oleh guru namun masih ada beberapa siswa yang belum aktif dalam mengikuti pembelajaran pendidikan agama Buddha.

Tahap akhir dari pertemuan pembelajaran pertemuan yang kedua ini guru dan peneliti memberikan soal post test yang sama soalnya dengan butir soal pre test dan angket keaktifan siswa. Sesudah dibagikan soal post test dan angket keaktifan siswa peneliti memberika petunjuk pengisian.Soal post test dan angket keaktifan siswa ini diberikan kepada siswa guna mengetahui pemahaman siswa mengenai materi dan mengetahui aktivitas yang dilakukan oleh siswa setelah proses belajar mengajar dengan menggunakan media alat peraga pada materi lambang-lambang Buddhis. Guru dan peneliti bersama-sama mengawasi siswa dalam mengerjakan soal. Setelah semua 
soal dikumpulkan dilanjutkan

guru memberikan kesimpulan.

Proses belajar mengajar ini

diakhiri dengan pembacaan doa

Namakarapatha dan dititup dengan salam Buddhis.

\section{Observasi}

Tahapan observasi ini ditunjukan ada kegiatan proses belajar mengajar dengan mencatat hal-hal yang penting serta mencatat kendala-kendala yang muncul pada proses belajar mengajar.

Observasi pembelajaran yang dilakukan oleh guru ini terkait dengan proses belajar mengajar dengan menggunakan media alat peraga pada materi lambang-lambang Buddhis.

Peneliti mengamati proses belajar mengajar ini secara keseluruhan proses belajar mengajar bahwa dapat dikatakan proses belajar mengajar berjalan dengan baik dan lancar. Hal yang menjadi kendala peneliti adalah hasil dari pemahaman siswa dengan mengetahui hasil pada evaluasi yang diberikan pada pre test dan post test dengan memperoleh hasil yang maksimal, terdapat siswa yang belum mencapai KKM, serta hasil dari perhitungan angket pada keaktifan siswa belum mendapatkan nilai dengan predikat baik hal tersebut menunjukan bahwa pada proses belajar mengajar siklus I belum tuntas.

Observasi peneliti pada siklus I adalah kegiatan pembelajaran diawali dengan pembacaan doa Namakarapatha yang dipimpin oleh siswa dan dilanjutkan dengan guru mengucapkan salam Buddhis. Guru mengabsensi siswa kelas I SD N Sokomoyo pada siklusI hadir semua.

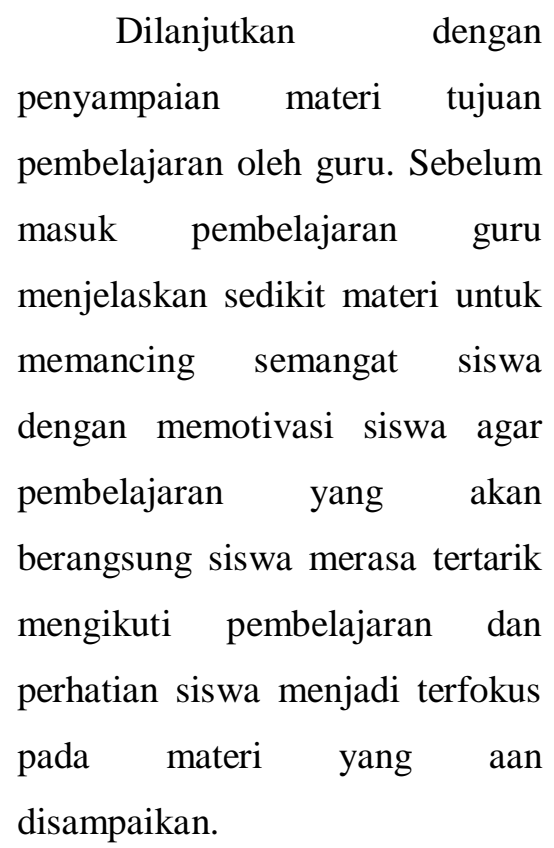
Penyampaian materi oleh guru dilakukan dengan menggunakan media alat peraga dan menyebutkan satu persatu dari masing-masing lambang Buddhis serta menyebutkan berbagai maknanya, pemebelajaran pada siklus I berjalan dengan lancar dan penuh perhatian, siswa sangat aktif dan 


$$
\begin{aligned}
& \text { merasa senang dalam mengikuti } \\
& \text { pembelajaran. Siswa sudah ada } \\
& \text { perubahan berbeda dengan } \\
& \text { sebelumnya dari cara menjawab } \\
& \text { pertanyaan dari guru pada saat } \\
& \text { proses belajar mengajar } \\
& \text { berlangsung, namun tidak } \\
& \text { semuanya aktif. Perhatian siswa } \\
& \text { lebih fokus dan sangat } \\
& \text { memperhatikan guru dalam } \\
& \text { penjelasan materi lambang- } \\
& \text { lambang Buddhis dengan } \\
& \text { menggunakan alat peraga. Proses } \\
& \text { belajar pada pendidikan agama } \\
& \text { Buddha berjalan dengan baik dan } \\
& \text { kondusif. }
\end{aligned}
$$

\section{Refleksi}

Berdasarkan hasil kegiatan evaluasi pada pembelajaran siklus I diketahui peneliti bahwa pembelajaran pada siklus I menggunakan media alat peraga pada materi lambang-lambang Buddhis belum berhasil secara maksimal dilihat dari hasil pre test dan post test serta aktivitas siswa belum berhasil sehingga perlu dilakukan tindakan yang kedua yaitu dengan melaksanakan siklus II sehingga proses belajar mengajar pendidikan agama Buddha dengan menggunakan media alat peraga memperoleh prestasi belajar yang baik di atas nilai KKM serta aktivitas siswa lebih meningkat dibandingkan dengan hasil pada siklus I.
Hasil refleksi pada siklus I meliputi kegiatan proses belajar mengajar pada materi lambanglambang Buddhis dengan menggunakan media alat peraga telah dilaksanakan dengan baik sehingga antusias siswa dan perhatian siswa menjadi terfokus pada materi, RPP pada pelaksanaan tindakan sudah baik. Pada proses belajar mengajar sudah sesuai dengan rencana pelaksanaan pembelajaran. Prestasi belajar dan aktivitas siswa sesudah proses belajar mengajar dengan menggunakan media alat peraga menujukan ada peningkatan dari pada proses belajar sebelum menggunakan media alat peraga yaitu terlihal dari hasil analisis aktivitas belajar dan hasil post test.

\section{Perencanaan siklus II}

\section{Perencanaan Siklus II}

Setelah diperoleh permasalahan pada proses belajar mengajar pendidikan agama Buddha kelas I dengan materi lambanglambang Buddhis menggunakan media alat peraga pada siklus I yang kurang maksimal dan terdapat siswa yang prestasi belajarnya masih dibawah KKM, serta masih ada siswa yang belum aktif dalam mengikuti pembelajaran sepeti yang sudah diketahui di hasil pengolahan 
data mengenai keaktifan belajar siswa hanya satu siswa yang mendapat predikat baik pada keaktifan belajar, maka peneliti melakukan perencanaan pembelajaran dengan siklus ke II. Sebelum pelaksanaan tindakan pada siklus ke II maka peneliti perlu mempersiapkan segala sesuatu yang menunjang lancarnya proses belajar mengajar yang sesuai dengan materi yang disampakan yaitu materi pembelajaran lambang-lambang Buddhis dengan menggunakan media alat peraga dengan semaksimal mungkin dan terprogram secara rinci dan matang, sehingga pembelajaran berhasil secara maksimal. Guna menunjang keberhasilan pada proses belajar mengajar pendidikan agama Buddha pada materi lambanglambang Buddhis dengan menggunakan media alat peraga maka peneliti persiapkan yaitu Rencana Pelaksanaan Pemelajaran (RPP), media alat peraga yang digunakan dalam mengajar, observasi guru, lembar observasi pembelajaran, intrumen tes meliputi pre test dan post test ke II, angket keaktifan siswa serta lembar wawancara.

\section{Pelaksanaan Siklus II}

a) Siklus II Pertemuan 1

Pada pertemuan pertama pembelajaran pendidikan agama Buddha, guru memberikan salam
Buddhis, dengan dilanjutkan pembacaan doa Namakarapatha yang dipimpin oleh salah satu siswa setelah itu guru mengabsensi siswa, menyampaikan tujuan pembelajaran memberikan dorongan motivasi dalam belajar, peneliti dan guru selanjutnya membagikan soal pre test II. Pre test ini dilakukan untuk mengetahui kemampuan siswa tentang materi lambang-lambang Buddhis. Setelah soal dibagikan peneliti memberikan pentunjuk pengisian kepada siswa, kemudian guru dan peneliti bersama-sama mengawasi siswa yang mengerjakan soal. Selesai pengerjaan soal dalam waktu 15 menit. Guru meneliti jawaban yang dikerjakan siswa dan memastikan soal dikerjakan semua.

Dilanjutkan kembali setelah tes dilakukan dengan guru memberikan gambaran serta menjelaskan mengenai arti dari lambang-lambang Buddhis dan siswa mendengarkan dengan tenang penuh konsentrasi mengenai tujuan pada proses belajar mengajar yang ingin dicapai yaitu menyebutkan macam-macam lambang Buddhis, menyebutkan makna lambanglambang Buddhis. 
Pada pertemuan ini guru memberikan motivasi-motivasi belajar kepada siswa, selanjutnya siswa diajak untuk tanya jawab meskipun siswa belum sepenuhnya aktif. Pertemuan I pada siklus II diakhiri dengan pembacaan doa Namakarapatha dan salam Buddhis oleh guru.

\section{b) Siklus II Pertemuan 2}

$$
\begin{aligned}
& \text { Pada pertemuan kedua, } \\
& \text { merupakan lanjutan dari } \\
& \text { penelitian pada pertemuan } \\
& \text { pertama pada siklus II ini. Pada } \\
& \text { pertemuan kedua guru dan } \\
& \text { peneliti bersama-sama } \\
& \text { berkolaborasi melaksanakan } \\
& \text { proses belajar mengajar dengan } \\
& \text { mengacu pada RPP. Kegiatan } \\
& \text { diawali dengan pembacaan doa } \\
& \text { Namakarapatha secara bersama- } \\
& \text { sama dan dipimpin oleh salah satu } \\
& \text { siswa dan dilanjutkan dengan } \\
& \text { salam Buddhis. Setelah itu guru } \\
& \text { mengabsensi siswa, } \\
& \text { menyampaikan tujuan } \\
& \text { pembelajaran yang akan dicapai } \\
& \text { serta pemberian motivasi- } \\
& \text { motivasi kepada siswa. } \\
& \text { Pada kegiatan inti proses } \\
& \text { belajar mengajar guru } \\
& \text { menjelaskan materi lambang- } \\
& \text { lambang Buddhis, guru } \\
& \text { menanyakan kembali mengenai } \\
& \text { materi yang sudah disampaikan } \\
& \text { pada pertemuan pertama, siswa } \\
& \text { sudah mulai aktif dan menjawab }
\end{aligned}
$$

pertanyaan meskipun dua siswa saja, berbeda dengan peneltian pada siklus pertama. Setelah itu guru menjelaskan materi dengan menggunakan media alat peraga pada materi lambang-lambang Buddhis, guru menyebutkan lambang-lambang Buddhis, menyebutkan satu persatu makna lambang-lambang Buddhis dengan menggunakan media alat peraga. Siswa antusias dan konsentrasi pada proses belajar mengajar, siswa mulai aktif dengan menjawab pertanyaanpertanyaan yang diberikan oleh guru hanya saja siswa yang aktif belum sepenuhnya dan ada siswa yang masih diam dan belum begitu paham mengenai materi yang disampaikan guru.

Dilanjutkan dengan memberikan soal post test serta angket penilaian aktivitas siswa guna mengetahui perkembangan siswa dalam keaktifan di dalam kelas serta mengetahui sejauh mana kemampuan siswa setelah mendapatkan materi yang di sampaikan oleh guru pada materi lambang-lambang Buddhis dengan menggunakan media alat peraga. Setelah dibagikan peneliti memberikan petunjuk pengisian soal dan angket. Guru dan peneliti memperhatikan dan mengawasi siswa dalam mengerjakan soal. 
Setelah semua soal dikumpulkan sebelum diakhiri dengan pembecaan doa guru memberikan kesimpulan pada materi yang sudah disampaikan dan memberikan kesempatan kepada siswa untuk menanyakan hal-hal yang belum di mengerti. Pada akhir pertemuan pada siklus ke II pertemuan ke dua diakhiri dengan pembacaan doa Namakarapatha secara bersama-sama yang dipimpin oleh salah satu siswa dan guru memberi salam Buddhis.

\section{Observasi}

Adanya perubahan aktivitas siswa dan guru pada proses belajar mengajar dari siklus I ke siklus II, proses belajar mengajar pada siklus ke II pada materi lambang-lambang Buddhis dengan menggunakan media alat peraga berlangsung sangat baik namun masih ada siswa yang belum sepenuhnya aktif dalam menjawab pertanyaan serta masih ada salah satu siswa yang belum mencapai ketuntasan belajar yaitu dengan nilai dibawah KKM.

Hasil observasi pada siklus II ini guru menyampaikan salam Buddhis, serta mengajak siswa untuk membacakan doa Namakarapatha secara bersama-sama dan dipimpin oleh salah satu siswa, dilanjutkan dengan guru mengabsensi siswa, pada proses belajar mengajar ini berlangsung dengan baik. Pada kegiatan pembelajaran diawali dengan menyampaikan tujuan pembelajaran, kemudian memberikan pertanyaan serta memberikan motivasi kepada siswa dengan baik dan siswa pun ada sedikit perubahan dalam keaktifan memberikan jawaban meskipun masih ada yang diam dan malu dalam menjawab pertanyaan.

Pada proses belajar mengajar pada siklus kedua ini mengalami peningkatan dibandingkan dengan siklus ke I terbukti dengan siswa ada yang aktif meskipun tidak semua siswa aktif. Setelah proses belajar mengajar dengan menggunakan media alat peraga pada materi lambang-lambang Buddhis selesai, guru memberikan tugas kepada siswa sesuai dengan materi yang terkait dan selesai dibahas. Kemudian guru memberikan soal evaluasi dan angket guna mengetahui kemampuan siswa dan mengetahui peningktan aktivitas siswa. Pembelajaran diakhiri dengan pembacaan doa Namakarapatha bersama-sama dan dilanjutkan dengan menyampaikan salam Buddhis dengan sangat baik.

\section{Refleksi}

Berdasarkan hasil refleksi pada siklus II pada proses belajar pendidikn agama Buddha dengan menggunakan media alat peraga pada materi lambang-lambang Buddhis pelaksanaan tindakan yang 
sudah baik sesuai dengan RPP yang telah direncanakan sebelumnya. Kegiatan proses belajar mengajar berlangsung sangat menarik dan pertatian siswa meskipun masih ada siswa yang belum maksimal dalam mengikuti pebelajaran, siklus II berlangsung dengan baik dan mengalami perubahan dibandingan dengan siklus-siklus sebelumnya.

Materi yang dijelaskan oleh guru sudah baik, pertanyaanpertanyaan yang diberikan oleh guru kepada siswa sudah mampu menjawab dengan baik meskipun masih ada kendala sebagian siswa masih pasif dan malu bertanya. Prestasi belajar dan keaktifan siswa pada materi lambang-lambang Buddhis dengan menggunakan alat peraga pada siklus II ini mulai ada peningkatan dibandingkan dengan siklus I. Pada siklus II pencapaian prestasi pada siswa mengalami peningkatan sebagian siswa bertambah 2 siswa mengalami peningkatan dengan hasil di atas KKM, namun masih ada salah satu siswa yang belum tuntas.

\section{Perencanaan Siklus III}

\section{Perencanaan Siklus III}

Setelah

diketahui

permasalahan pada proses belajar pendidikan agama Buddha kelas I dengan menggunakan media alat peraga pada materi lambanglambang Buddhis di siklus II yang kurang maksimal masih terdapat siswa yang prestasi belajarnya belum mencapai KKM serta masih terdapat siswa yang keaktifanya belum maksimal dikarenakan ada siswa yang belum mendapakan predikat baik pada penilaian keaktifan belajar. Sebelum pelaksanaan tindakan di dalam kelas pada siklus III, peneliti yaitu mempersiapkan segala sesuatu yang dapat menunjang lancarnya proses belajar mengajar yang sesuai dengan materi pembelajaran menggunakan media alat peraga pada materi lambang-lambang Buddhis yang bagus dan matang. Hal-hal tersebut yaitu Rencana Pelaksanaan Pembelajaran (RPP), media alat peraga yang digunakan dalam mengajar, observasi guru, instrumen tes meliputi pre test III dan post test III serta angket penilaian aktivitas siswa dan lembar wawancara.

\section{Pelaksanaan Siklus III}

\section{a) Siklus III Pertemuan 1}

Pada awal pertemuan pembelajaran siklus III pertemuan I guru memberikan salam Buddhis, dilanjutkan dengan berdoa bersama dengan membacakan Namakarapatha yang dipimpin oleh salah satu siswa. Setelah itu guru mengabsensi siswa, menyampaikan tujuan pembelajaran, serta memberikan 
semangat dan motivasi kepada siswa untuk belajar, dilanjutkan dengan guru berkolaborasi dengan peneliti memberikan soal pre test III.

Pre test III ini dilakukan untuk mengetahui kemampuan siswa tentang materi pokok lambang-lambang Buddhis. Soal dibagikan peneliti memberikan petunjuk pengisian dalam mengerjakan soal kepada siswa, kemudian guru dan peneliti bersama-sama memperhatikan dan mengawasi siswa yang sedang mengerjakan soal. Soal dapat terselesaikan dalam waktu 15 menit. Guru meneliti jawaban soal yang telah dikumpulkan dan memastikan semua soal dapat dikerjakan dengan benar. Selanjutnya guru memberikan gambaran mengenai materi yang disampaikan dan menerangkan lambang-lambang dalam agama Buddha, siswa antusias dalam memperhatikan penyampaian guru dan siswa mengerti mengenai tujuan pembelajaran yang hendak dicapai.

Pada pertemuan ini guru memberikan motivasi-motivasi kepada siswa, siswa diajak untuk melakukan tanya jawab mengenai materi yang belum mampu dipahami siswa pun sudah aktif dalam bertanya maupun dalam menjawab pertanyaan guru. Tahap yang terakhir yaitu penutup dilanjutkan dengan pembacaan doa Namakarapatha yang dipimpin oleh salah satu siswa dan guru memberikan salam Buddhis.

\section{b) Siklus III Pertemuan 2}

Pada pertemuan yang kedua penelitian ini adalah penelitian lanjutan dari pertemuan yang pertama pada siklus ke III. Pada pertemuan kedua guru dan peneliti berkolaborasi untuk melaksanakan proses belajar mengajar. Pada kegiatan belajar pada pertemuan kedua masih mengacu pada RPP dan pembelajaran menggunakan media alat peraga guna menunjang keberhasilan serta memperjelas materi yag akan disampaikan. Pada pertemuan kedua ini diawali dengan pembacaan doa Namakarapatha yang dipimpin oleh salah satu siswa, dilanjutkan guru memberikan salam Buddhis. Setelah itu guru mengabsensi siswa serta menyampaikan tujuan pembelajaran yang hendak dicapai dan memberikan motivasi dengan cerita-cerita jataka dari Sang Buddha hal ini 
dilakukan supaya siswa tidak jenuh serta tidak bosan dalam mengikuti pembelajaran.

Pada kegiatan inti pertemuan kedua ini guru menyampaikan tujuan pembelajaran yang hendak dicapai dan menjelaskan materi mengenai lambang-lambang Buddhis dengan menggunakan media alat peraga dengan menyebutkan macam-macm lambang-lambang Buddhis, menyebutkan masing-masing makna dari lambang-lambang Buddhis. Guru memberikan pertanyaan-pertanyaan kepada siswa tentang materi yang sudah disampaikan, siswa terlihat aktif dalam menjawab pertanyaan yang diberikan oleh guru.

Selanjutnya guru dan peneliti berkolaborasi kembali dengan memberikan soal post test III dan angket penilaian keaktifan kepada siswa dengan angket yang sama dan soal yang sama digunakan pada soal pre test III dan Post test III serta pengisian angket keaktifan siswa ini dilakukan guna mengetahui kemampuan siswa dalam memahami materi yang sudah disampaikan oleh guru serta mengetahui peningkatan aktivitas siswa di dalam kelas pada materi lambang-lambang
Buddhis dengan menggunakan media alat peraga. Sebelum soal post test III dan angket keaktifan siswa dibagikan peneliti memberikan petunjuk pengisisan. Guru dan peneliti memperhatikan dan mengawasi siswa dalam mengerjakan soal.

Setelah soal dan angket telah selesai dikerjakan guru memberikan kesimpulan mengenai materi yang telah usai disampaikan sebelumnya serta memberikan kesempatan kepada siswa untuk bertanya mengenai materi-materi yang belum bisa dipahami. Pada tahap akhir yaitu penutup dengan pembacaan doa Namakarapatha yang dipimpin oleh salah satu siswa dan diakhiri dengan salam Buddhis.

\section{Observasi}

Pengamatan ditujukan adanya peningkatan pada aktivitas siswa yang sudah baik dari siklus II ke siklus III. Pada proses belajar mengajar pendidikan agama Buddha pada materi lambang-lambang Buddhis di kelas I berlangsung dengan baik.

Hasil observasi pada proses belajar mengajar pada siklus III guru menyampaikan salam Buddhis dengan baik, guru mengajak siswa membaca doa Namakarapatha dengan baik, guru mengabsensi 
siswa dengan baik. Kegiatan

pembelajaran diawali dengan

penyampaian tujuan pembelajaran

yang akan dicapai kemudian guru memberikan pertanyaan kepada siswa serta memberikan motivasi dengan baik kepada siswa, siswa pun antusias dalam menjawab.

Pada proses belajar mengajar di siklus ke III mengalami peningkatan dan semakin membaik dari pada di siklus I dan II terbukti dengan siswa terlihat tenang dan sangat memperhatikan guru serta antusias dalam mengikuti pembelajaran. Siswa aktif dalam bertanya maupun menjawab pertanyaan yang diberikan oleh guru pada pemeblajaran siklus III berjalan dengan baik. Perhatian siswa terhadap media alat peraga yang digunakan guru dalam menyampaikan materi lambanglambang Buddhis sudah baik. Guru memberikan pertanyaan kepada siswa dalam proses belajar mengajar keseluruhan siswa dapat menjawab pertanyaan dengan baik dengan penuh percaya diri. Setelah proses belajar mengajar pendidikan agama Buddha selesai guru memberikan tugas kepada masing-masing siswa sesuai materi yang telah dibahas. Kemudia pembelajaran diakhiri dengan pembacaan doa Namakarapatha yang dipimpin oleh salah sat siswa dan guru menyampaikan salam Buddhis dengan sangat baik.

\section{Refleksi}

Berdasarkan hasil refleksi pada proses belajar mengajar di siklus III, kegiatan proses belajar mengajar pendidikan agama Buddha kelas I di Sekolah Dasar Negeri II Sokomoyo di kabupaten Kulon Progo Yogyakarta pada materi lambang-lambang Buddhis dengan menggunakan media alat peraga pelaksanaan tindakan sudah baik sesuai RPP. Keiatan proses pembelajatran berlangsung sangat menarik siswa sangat senang dalam mengikuti pembelajaran dan siswa dalam belajar memperhatikan guru serta terfokus dalam materi yang disampaikan pembelajaran pada siklus III berlangsung dengan sanagat baik dibandingkan dengan siklus II.

Materi lambang-lambang Buddhis yang dielaskan oleh guru dengan menggunakan media alat peraga sudah baik. Pertanyaanpertanyaan yang diberikan oleh guru siswa mampu menjawab semua dengan sempurna. Pada prestasi belajar siswa dan keaktifan siswa di siklus ke III ini siswa mengalami perubahan dengan baik dibandingkan dengan siklus-siklus sebelumnya, prestasi siswa serta keaktifan siswa pun meningkat dengan baik. Siswa keseluruhan sudah mencapai hasil 
siatas KKM serta aktivitas siswa pun semua mendapat predikat baik apabila dibuat dalam prosentase keberhasilan pada siklus ke III ini adalah $100 \%$ tuntas dengan baik.

\section{KESIMPULAN}

Berdasarkan penelitian tindakan kelas, hasil pengolahan data mengenai aktivitas belajar siswa pada siklus I satu siswa mendapatkan kriteria Baik dengan jumlah nilai 20, pada siklus II meningkat menjadai 3 Siswa dengan mendapatkan nilai $(19,33)$, $(18,67),(20)$ dan pada siklus III semua siswa mendapatkan kriteria penilaian Baik, dikarenakan perolehan nilai di atas 19,33 dengan rincian hasil (19,33), dengan mendapatkan nilai 20 Tiga siswa dan 19,33 Dua siswa dengan demikian dari siklus ISiklus III selalu ada penigkatan perolehan nilai. Prestasi belajar siswa kelas I pada proses belajar mengajar pendidikan agama Buddha dengan menggunakan media alat peraga meningkat dari siklus I, siklus II dan siklus III. Prestasi belajar siswa tersebut meningkat pada siklus I yaitu 40\% (2 siswa tuntas dengan nilai di atas KKM), dan siklus II yaitu 60\% (3 siswa tuntas dengan nilai di atas KKM) menunjukan peningkatan 20\%. Siklus III meningkat lagi 100\% keseluruhan siswa kelas I dengan jumlah 5 siswa tuntas semua dengan memperoleh nilai di atas KKM.

\section{DAFTAR PUSTAKA}

Azhar Arsyad. (2011). Media Pembelajaran. Jakarta: PT. Raja Grafindo Persada.

Bhikkhu Buddhaghosa. (2007). Dhammapada \& Buddhist Legends. Jakarta: Perpustakaan Narada.
Bodhi. (2010). Kotbah-kotbah berkelompok Sang Buddha. Jakarta Barat: Dhammacitta.

Daryanto.(2010). MediaPembelajaran Perananya Sangat Penting Dalam Mencapai Tujuan Pembelajaran. Yogyakarta: Gava Media

Departemen Pendidikan Nasional.(2003). Undang-Undang Republik Indonesia No. 20 Tahun 2003 Tentang Sistem Pendidikan Nasional. Jakarta : Direktorat Jenderal Pendidikan Dasar dan Menengah.

Gerlach \& Ely. (1971). Teaching and Media. Englewood Chliffs: Prentice-Hall, Inc.

Hamzah \& Nina. (2011). Teknologi Informasi \& Komunikasi Pembelajaran.Jakarta: PT Bumi Aksara.

Hasan.(2007). Kamus Besar Bahasa Indonesia. Jakarta: Balai Pusta

Hujair Sanaky.(2009). Media Pembelajaran. Yogyakarta: Safiria Insani Pers.

Krishnanda Wijaya-Mukti. (2003). Wacana Buddha Dhamma. Jakarta: Yayasan Dharma Pembangunan.

Lanny Anggawati dan Wena Cintiawati.(2000). Panduan Tipitaka Kitab Suci Agama Buddha. Klaten: Vihara Bodhivamsa

Mulyono Abdurrahman.(1999). Pendidikan BagiAnakBerkesulitanBelajar. Jakarta: Rineka Cipta.

Nana Sudjana \& Ahmad Rivai.(2009). Media Pengajaran. Bandung: Sinar Baru Algesindo.

Pius A. Partanto . Dahlan Al Barry.(1994). Kamus Ilmiah Populer. Surabaya: Arkola.

Rochiati Wiriaatmadja. (2008). Metode Penelitian Tindakan Kelas Untuk Meningkatkan Kinerja Guru dan Dosen. Bandung: Rosdakarya. 
Nivedana - Jurnal Komunikasi \& Bahasa

Volume 1, No 1, Juli 2020

Sadiman, Arief S. dkk.(2009). Media Pendidikan: Pengertian,

Pengembangan, dan Pemanfaatannya. Jakarta: Raja Grafindo Persada.

---------.(2005). Media Pendidikan Pengertian, Pengembangan, dan Pemanfaatannya. Jakarta: PT Raja Grafindo Persada.

Sardiman, A.M. (2000). Interaksi dan Motivasi Belajar Mengajar. Jakarta: PT Raja Grafindo Persada

Slameto.(2003). Belajar dan Faktor-faktor yang Mempengaruhinya. Jakarta: RinekaCipta.

Suharsimi Suharsimi. (2002). Prosedur Penelitian, Suatu Pendekatan Praktik. Jakarta: Rineka Karya.

Suharsimi Arikunto dkk. (2010). Penelitian Tindakan Kelas. Jakarta: PT. Bumi Aksara.

(2012) Penelitian Aksara.

Wijaya.(2007). Kemampuan Dasar Guru Dalam Proses Belajar Mengajar. Bandung: PT.Remaja Rosda Karya

Wina Sanjaya. (2006). Strategi Pembelajaran Berorientasi Standar Proses Pendidikan. Jakarta: Kencana. 